
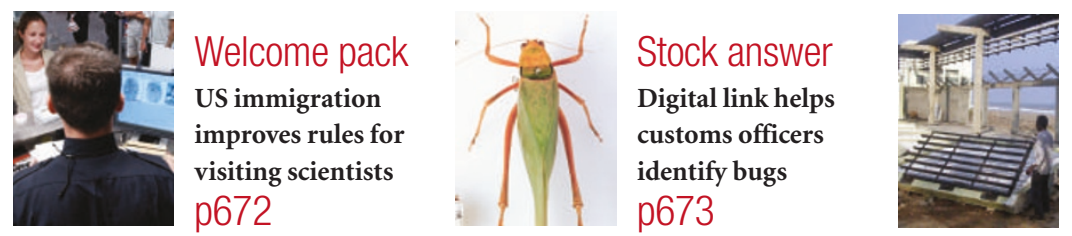

Power struggle
Flooded reactor
reignites India's
energy debate
p675

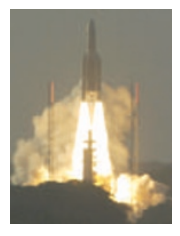

Weight lifter

Europe's updated

Ariane rocket blasts

off successfully

p676

\title{
Salt sellers challenge US health agency using data-quality act
}

\section{Meredith Wadman, Washington}

Health agencies in the United States are being leant on by the private sector to release the raw data that underpin disputed government regulations.

The pressure is being brought to bear through the Data Quality Act, a law championed by the Bush administration. The act allows companies, activist groups and citizens to challenge government statements and rules, prompting corrections if the government cannot demonstrate their scientific validity.

The measure worried scientists when it took effect in late 2002 (see Nature 416, 249; 2002). Its effect is now being felt at several research agencies - including the National Institutes of Health (NIH). As early as this summer, for example, a US Court of Appeals will judge a plea from the Virginia-based Salt Institute, which represents salt producers. The institute wants direct access to the data behind a study that linked salt consumption to high blood pressure.

The trial, funded by the National Heart, Lung, and Blood Institute (NHLBI), studied the impact of dietary sodium intake on blood pressure and the results were published in The New England Journal of Medicine, Annals of Internal Medicineand The American Journal of Cardiology. They showed that reducing dietary sodium lowers blood pressure in most people, and this led the government to recommend that Americans consume less salt.

Researchers in the trial say that they have released all the data the Salt Institute could want or need - and that it is misusing the act. "It is trying to slice and dice the data set so it finds a group that seems not to have a blood pressure that's responsive to reduction in salt," says Lawrence Appel, a physician at Johns Hopkins School of Public Health in Baltimore, Maryland, and one of the trial's principal investigators. "That's blatantly inconsistent with a scientific approach to analysing clinical data."

Last month, the Salt Institute and the US

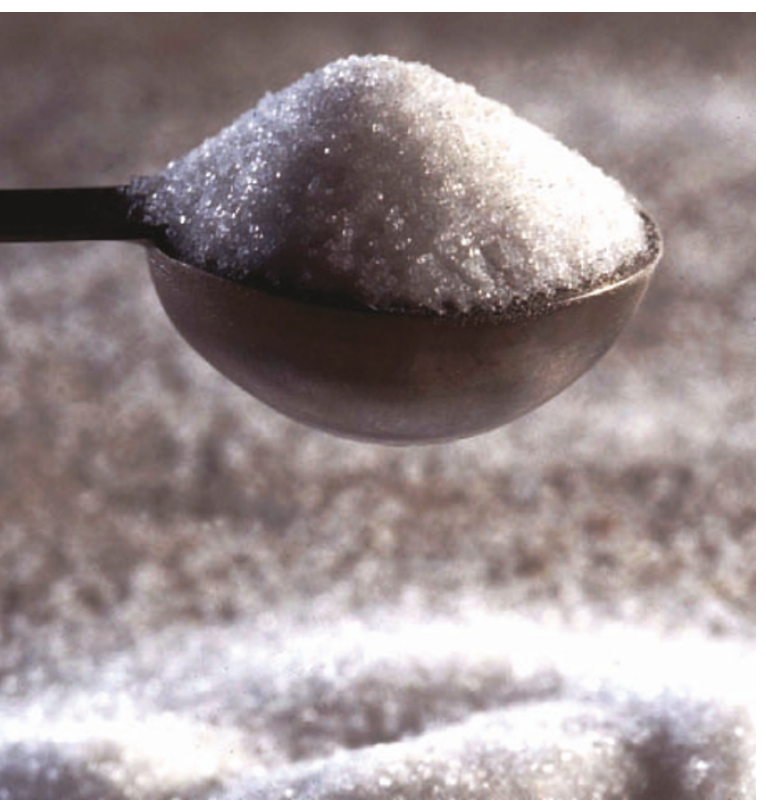

poon-fed: the Salt Institute is fighting for access to unpublished data.

challenged the chemical review procedures of the NIH-run National Toxicology Program and its investigation of possible carcinogens.

However, the salt case marks the first time that a petitioner has actually sued under the Data Quality Act. In other cases, complainants have simply petitioned the relevant government agencies. The Washington Post reported last summer that, since the law came into force, industry has filed four-fifths of the substantive petitions under the law; environmental or citizen groups have filed the others.

The petitions have targeted bodies such as the Environmental Protection Agency and the Fish and Wildlife Service. Last month, the Fish and Wildlife Service decided not to list the sage grouse as an endangered species, against environmentalists' advice, after an

Chamber of Commerce asked the Fourth Circuit Court of Appeals to overturn a decision by a lower court in Virginia. That court had ruled that the NHLBI was within its rights in refusing to release the data that had been requested.

"If any agency deserves to be sued, here's one," says Richard Hanneman, the president of the Salt Institute. He says that the NHLBI has shown a consistent "pattern of obfuscation and non-responsiveness" over requests for access to unpublished data, such as the initial blood pressures of the trial's 412 subjects.

The NHLBI declined to comment while the matter is before the courts.

\section{Rising pressure}

The salt case is the latest in a flurry of dataquality actions against NIH institutes. Last year, for example, the National Institute on Aging rewrote a statement on its website, which claimed that chewing tobacco is as bad for health as smoking, after a private think-tank, funded by conservative activist Richard Scaife, requested a correction. And Jim Tozzi, the industry-affiliated lobbyist who actually wrote most of the law, has industry group and a county board in Idaho challenged the data that the agency was using to support the listing.

Critics of the act say that it was devised primarily as a tool for conservatives to attack unwelcome regulations by picking at isolated pieces of the science behind them, rather than weighing all the evidence and coming to appropriate conclusions.

"The effort is to suppress the science, to destroy its credibility even though it's widely available and has been vetted many times," says Rena Steinzor, a law professor at the University of Maryland in Baltimore.

The law's backers sharply disagree. Tozzi says that when federal policies have effects that cost millions or billions of dollars, the public should have an opportunity to challenge the science behind them. Now an adviser at the Center for Regulatory Effectiveness, a Washington-based government watchdog, Tozzi says that the great majority of scientists should be unaffected by the act. But if scientists "are going to get in the regulatory sandbox, they gotta play by these rules", he says. "They can't use their white coats to shield them from the sunlight." 